\title{
MAKING SENSE OF CLASSICAL THEORY
}

\author{
BY \\ STEVEN KATES
}

What made the Keynesian Revolution revolutionary was that it introduced demand deficiency into the theory of the cycle. Although John Maynard Keynes called it "Ricardo's doctrine," this is what Say's Law means, whose rejection was the central aim of The General Theory. "Malthus, indeed, had vehemently opposed Ricardo's doctrine that it was impossible for effective demand to be deficient" (Keynes 1936, p. 32; underlining and italics added).

Joan Robinson makes the same point: "The old orthodoxy, against which the Keynesian revolution was raised, was based on Say's Law-there cannot be a deficiency of demand" (Robinson 1976, p. 121).

This is David Ricardo replying to Robert Malthus in 1820 where they were discussing the recessions that had followed the end of the Napoleonic Wars. Malthus argued high unemployment had been caused by too much saving and not enough spending, to which Ricardo replied: "[The actual problem is that] men err in their productions, there is no deficiency of demand" (Ricardo 1951-73, 8, p. 277).

Without understanding demand deficiency as the core difference between the classical theory of the cycle and modern macro, it is impossible to make sense of the crucial issues that matter.

In responding to the papers by Roy Grieve and James Ahiakpor in the present volume, let me first turn to Ahiakpor. Ahiakpor says things I agree with, but some I do not, the most important of which is found in his very first line: "Say's Law explains the coordination of markets for produced goods and services (not labor) by variations in relative prices" (Ahiakpor, present volume, hereinafter 2018, p. 267).

That is not Say's Law. While Ahiakpor defends various points made by John Stuart Mill, he does not explain other than through a series of bits and pieces why Keynes and Grieve are wrong, or why classical theory is a better guide than modern macro for understanding the causes of recession and the subsequent recovery. Unless one explicitly points out that demand deficiency played no role in classical theory, with its very inclusion actively rejected, the central point around which the differences between classical theory and Keynesian macro disappears.

Worse still, Ahiakpor argues "[Say's Law] does not apply to labor services" (ibid., p. 268). Mill was very specific that "demand for commodities is not demand for labour," which is the very essence of Say's Law (comprehensively discussed in Kates 2015).

Steven Kates, Associate Professor, RMIT University, Melbourne. Contact: steve.kates@ rmit.edu.au. I would like to thank the editor of this journal, Stephen Meardon, for his many comments and suggestions. As usual, however, responsibility for the contents of the article rests entirely with the author. 
Grieve, for his part, kept away from trying to explain why Mill was wrong, but dealt only with why Keynes was right. Of course, if Keynes is right, Say's Law is wrong. But if Say's Law is right, then Keynes is wrong, along with virtually the whole of modern macroeconomic theory. That is the issue on the table.

And while I disagree with Grieve's papers root and branch, he does bring what matters into the conversation. The major question he asks is whether classical economics can explain the actual realities of recession, which economists since Keynes have resolutely denied. Grieve, moreover, focuses on the economics of John Stuart Mill, the deepest, most articulate defender of classical theory.

In the brief space allotted, I cannot respond to everything Grieve has said, but only point out in a general way why he has been unable to follow Mill's reasoning. The fundamental problem is the shifts in the conceptual base of economic theory that followed the publication of The General Theory, along with various technical terms being given different meanings, which have made it almost impossible for modern economists to comprehend classical theory. There were many such shifts, but I will restrict myself to three.

First, it was to conceptualize economic flows in relation to money. This is Keynes:

Contemporary economists, who might hesitate to agree with Mill, do not hesitate to accept conclusions which require Mill's doctrine as their premise. The conviction, which runs, for example, through almost all Professor Pigou's work, that money makes no real difference except frictionally and that the theory of production and employment can be worked out (like Mill's) as being based on 'real' exchanges with money introduced perfunctorily in a later chapter, is the modern version of the classical tradition. (Keynes 1936, pp. 19-20)

Classical economists did indeed conceptualize the flow of product in real terms-one of the definitions of Say's Law is, after all, that goods buy goods - and only afterwards introduce the complicating factor of money. But the devastation that often occurred because of financial dislocations was hardly seen as "perfunctory," and neither were their effects seen as brief. Because of Keynes, our modern understanding of the processes of an economy is almost entirely based on money flows.

Where this matters very sharply, and this is my second point, is in relation to our understanding of "saving." The Keynesian bequest is to conceptualize "saving" as a flow variable, the monetary difference between current income and current consumption. "Saving" is defined as a failure to spend, which is seen as the principal cause of recession. A classical economist thought of "saving" very differently, in real terms, as that part of the stock of the existing resource base devoted either to maintaining capital, or to producing additional capital aimed at increasing the future flow of output.

In classical theory saving was the proportion of all existing land, labor, and capital used to add to the productive base of the economy. Saving was literally investment, of which there could not be too much. Value-adding forms of investment drove an economy forward. Keynesian economics was originally a theory of recession, but is now taught as if productive value-adding investment and non-productive government spending (I and $G$ ) are for all practical purposes identical in their effects on growth and employment, since both add to demand while drawing down on supposedly excessive levels of saving. 
In terms of the cycle, according to classical theory, after the onset of recession, owners of capital would try to find others to pay for use of the capital items they owned (in the same way an unemployed worker would look for a job). Savings were never left intentionally idle. In modern economic theory, however, saving is the money difference between current income and consumption. Idle money balances are supposedly evidence of excess levels of saving.

Third, a general glut is not a synonym for recession. Say's Law states recessions are never caused by oversaving and demand deficiency - a general glut-but in no sense denies there are many other circumstances that do cause recessions.

Let me therefore provide a model of recession from a classical perspective (from Kates 2017, ch. 15). The diagram shows a straight-line Production Possibility Curve (PPC). The vertical axis shows current consumption (C) and government spending (G) on items not directed towards increasing the future flow of output. The horizontal axis shows investment (I), forms of production intended to increase the economy's ability to produce. Value-adding forms of public investment are included in I.

The interior of the PPC is the economy in full, with the area above the horizontal dotted line roughly the proportion of the economy's resource base saved and therefore invested. All production, whether for current consumption or investment, draws down on the economy's resource base, pulling the PPC inwards. Only investment attempts to put more back in than is withdrawn, which, if properly channeled, pushes the PPC out. From a classical perspective, an economy is driven from the interior to the exterior. Demand for $\mathrm{C}, \mathrm{I}$, and $\mathrm{G}$ is the consequence of economic activity, not its cause.

A recession (where I falls from the full employment level, $\mathrm{I}(\mathrm{C}+\mathrm{G})$ fe to the recession level, $\mathrm{I}(\mathrm{C}+\mathrm{G}) \mathrm{r})$ takes an economy from A to R. A Keynesian stimulus attempts to raise

\section{$\mathbf{C}$ and $\mathbf{G}$}

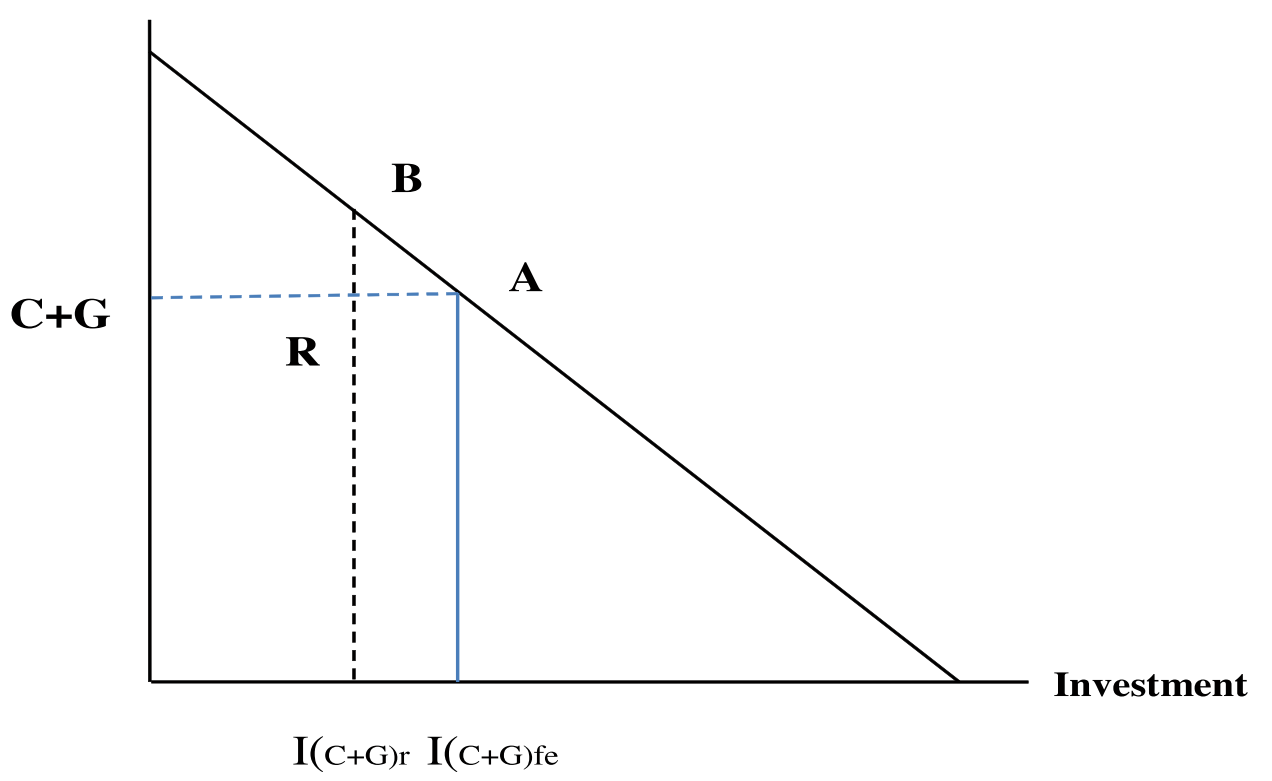

FIGURE 1. Supply Creates Demand. 
$\mathrm{G}$ to bring the economy towards B. Classical policy would instead attempt to return the economy to A. Should the economy reach B, or some point between A and B, the now lower level of investment would lead to a slowing of real income and economic growth.

Let us finally turn to Grieve's supposedly killer point: the effect of sudden large increases in saving by the wealthy (Grieve, present volume, hereinafter 2018, p. 275), ironically the example Mill had himself designed to prove demand deficiency was impossible. If that occurred, there might well be a slowdown, since the structure of production would no longer conform to the structure of demand. But what would also happen would be a shift of capital (and labor) into the production of goods and services for the non-wealthy. Grieve cannot follow Mill's point because he conceives the adjustment process is driven from the demand side: "Mill is incorrect in arguing that, in the circumstances envisaged, workers' expenditure can be relied upon to make up for effective demand lost through the new frugality of the propertied classes" (Grieve 2018, p. 276).

Mill instead thinks in real terms and from the supply side. What Mill and classical economists would expect is that the owners of capital would shift as best they could whatever physical forms of capital they already had into the kinds of production the non-wealthy might be willing to buy, while entrepreneurs would collectively reconfigure the capital stock of the nation to produce products they believed they could sell. It would never have occurred to Mill that products could not find a market in the circumstances of 1848 (or today, for that matter), or that entrepreneurs would give up trying to produce things they believed others might be willing to buy.

To describe Mill's analysis as "confused" and to say Mill's fourth proposition on capital "makes no sense" (Grieve 2018, p. 276) are absurd. Only five years before publishing his Principles, Mill wrote arguably the greatest text on logic published in English during the nineteenth century. Grieve should do more than give Mill the benefit of the doubt. He should return to Mill's text with a generous portion of humility in trying to make sense of what may well be the greatest economics text ever written, but one which, as Grieve's failure to comprehend Mill's argument powerfully demonstrates, a modern economist is almost completely unable to understand.

\section{REFERENCES}

Ahiakpor, James C. W. 2018. “Keynes, Mill, and Say’s Law: A Comment on Roy Grieve's Mistaken Criticisms of Mill." Journal of the History of Economic Thought 40 (2): 267-273.

Grieve, Roy H. 2016. “Keynes, Mill, and Say's Law: The Legitimate Case Keynes Didn’t Make against J. S. Mill." Journal of the History of Economic Thought 38 (3): 329-349.

_ 2017. "Kates on Mill's Fourth Proposition on Capital: Why All the Fuss?" Journal of the History of Economic Thought 39 (2): 271-272.

- 2018. "Off Target: Professor Ahiakpor on Keynes, Mill, and Say's Law." Journal of the History of Economic Thought 40 (2): 275-278.

Kates, Steven. 2015. "Mill's Fourth Fundamental Proposition on Capital: A Paradox Explained." Journal of the History of Economic Thought 37: 39-56.

- 2017. Free Market Economics: An Introduction for the General Reader. Cheltenham: Edward Elgar. Keynes, John Maynard. 1936. The General Theory of Employment, Interest and Money. London: Macmillan. 
Mill, John Stuart. [1871] 1921. Principles of Political Economy with Some of Their Applications to Social Philosophy. Seventh edition. London: Longmans, Green, and Co.

Ricardo, David. 1951-73. The Works and Correspondence of David Ricardo. Edited by P. Sraffa with M. H. Dobb. Volume VIII, Letters, 1819-June 1821. Cambridge: Cambridge University Press.

Robinson, Joan. 1976. “The Age of Growth.” In Joan Robinson, ed., Collected Economic Papers. Volume 5. Oxford: Basil Blackwell, pp. 120-129. 